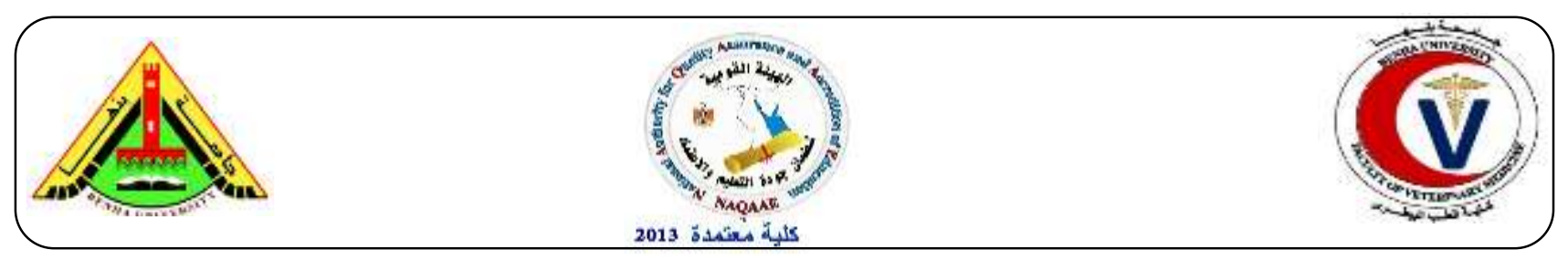

\title{
Parasitic affections of edible offals of slaughtered animals at El-Shohada abattoir, Menofia governorate, Egypt
}

\author{
Ghada El-Meleh $^{1}$, Rasha El-Meghanawy ${ }^{2}$, Islam Sabike ${ }^{1}$, Mohammed Hassan ${ }^{1}$ \\ ${ }^{1}$ Department of Food Hygiene, Faculty of Veterinary Medicine, Benha University \\ ${ }^{2}$ Animal Health Research Institute, Shibin El Kom Branch, Egypt
}

\section{A B S T R A C T}

A total of 5853 animals slaughtered at El-Shohada abattoir, Menoufia governorate, Egypt represented by 670 camel, 340 cattle, 366 buffalo, 3188 young cattle, 502 young buffalo, 544 sheep and 243 goats were inspected from 21 Dec., 2017 to 20 Dec., 2018 to evaluate the incidence of some parasitic infections (Hydatidosis, Fascioliasis, Cysticercosis and Sarcocystosis) according to seasonal variation. Otherwise, the study aimed to detect the microscopic form of sarcosystic affection in 18 esophageal samples from 6 buffalo ( 3 suspected and 3 apparently healthy), 3 cattle, 3 sheep, 3 goats and 3 camel by using Polymerase Chain Reaction (PCR). The incidence of hydatidosis was $18 \%, 0.3 \%$ and $0.5 \%$ in camel, cattle and buffalo, respectively while it couldn't be detected in young cattle, young buffalo, sheep and goat. The highest total incidence of hydatidosis was recorded in winter (13\%). The incidence of fascioliasis was $0.9 \%$ in camel, $0.8 \%$ in buffalo, $1.2 \%$ in cattle and $0.1 \%$ in young cattle, but it couldn't be detected in young buffalo, sheep and goat. The cysticercosis couldn't be detected in edible offals of slaughtered animals during the period of the study. Sarcocyst fusiforms was detected in edible offals $(22.9 \%$ in esophagus and $3.7 \%$ in tongue) of $62.8 \%$ of buffaloes and $0.2 \%$ of the young ones with the highest incidence (42\%) was recorded in autumn. PCR reading showed that all 3 samples confirmed positive for suspected buffaloes, one of 3 samples confirmed positive for apparently healthy buffaloes, one of three samples confirmed positive for cattle, 2 of 3 samples confirmed positive for sheep, one of 3 samples confirmed positive for goat and three samples were confirmed negative for camel. The present study concluded that there is a need to educate consumers, food handlers and all others who have access to food about the importance of hygiene and it is necessary for cooking food properly.

Keywords: Incidence, Hydatidosis, Fascioliasis, Cysticercosis, Sarcocystosis.

Received: 25 June 2019, Accepted: 21 June 2019 (http://www.bvmj.bu.edu.eg) (BVMJ-36(2): 117-128, 2019)

\section{INTRODUCTION}

Food And Agriculture Organization and also, World Health Organization (FAO/WHO, Codex Alimentarius Commission) defined the edible offal of slaughtered animals as offals that have been passed as fit for human consumption. According to Kenya Standard
Offal - Specification, the edible offal are those parts of the carcass that has been passed as fit for human consumption. In the case of food animals, these include red offal, green offal and white offal. Red offal include heart, liver, kidney, spleen, tongue, lungs, pancreas. 
Green offal includes the rumen, reticulum, omasum, abomasum, small intestines, large intestines, colon, and gizzards. White offal includes the brain, spine, bone marrow, testicles and teats. Zoonotic parasites can be classified into four categories, direct zoonotic parasites which infect human directly from animals. Metazoonotic parasites as Fasciola spp. which can infect humans from invertebrate intermediate hosts. Cyclozoonotic parasites have vertebrate intermediate hosts and include Echinococcus granulosus and Taenia saginata, finally saprozoonotic parasites can infect human from soil or water (Ahmed, 2014). Hydatidosis is a widespread zoonosis infesting many animals and human. Even though the dog tapeworm (Echinococcus granulosus) is the smallest cestode, It has the largest metacestode. The intermediate hosts are herbivorous animals as cattle, sheep and camels. The final host is dog (Bouree, 2001). Fascioliasis is a foodborne zoonotic disease caused by Fasciola species which is a trematode predominantly found in ruminants (cattle, buffalo, sheep and goats), but can also infect humans (Ashrafi et al., 2014). Fascioliasis reduces animal productivity, weight gain and the production of meat and milk. In addition, it causes moderate icterus, metabolic disorders, and secondary infections due to decrease immunity by chronic fascioliasis and liver condemnation during postmortem inspection in slaughterhouses, while the acute fascioliasis may lead to mortalities (Mason, 2004). Bovine cysticercosis is a disease caused by Teania saginata larvae as one of the major parasitic diseases. Cattle act as intermediate host; while man is a definitive host. The disease has worldwide distribution and transmitted to human mainly by consumption of raw or undercooked meat. The lungs, heart, liver, tongue, shoulder muscle, masseter muscle and diaphragm are the predilection sites for this parasite. Eating of cooked meat and proper hygienic practices should be incorporated in the prevention and control of the disease (Alemneh et al., 2017). Sarcocystis infection is a parasitic zoonosis, which may cause acute and fatal clinical diseases in susceptible animal. When raw or undercooked infected beef is consumed by man, it may result in intestinal sarcocystosis (Ifeoma et al., 2013). Sarcocystosis infections in human and animals are caused by singlecelled, cyst-forming, intracellular protozoan parasites in the family of Sarcocystidae (Hamidinejat et al., 2015). Among different known species of Sarcocystis in cattle, only Sarcocystis hominis is important from the public health viewpoint, because of its zoonotic characteristics (Hajimohammadi et al., 2014). The parasite is transmitted either fecal-orally or by the ingestion of undercooked meat containing sarcocysts (Scott, 2004). The current study focused to evaluate the incidence of hydatidosis, fascioliasis, cysticercosis and sarcocystosis in edible offals of slaughtered animals from 22 Dec., 2017 to 21 Dec., 2018 during detailed post- mortem examination and detection of microsarcocysts by using Polymerase Chain Reaction according to the following objects:

1- Estimation of the incidence of the studied parasitic affections in food slaughtered animals and in its edible offals.

2- Estimation of the incidence of parasitic affections according to seasonal variation.

3- Detection of microsarcocysts by using Polymerase Chain Reaction.

\section{Materials and methods}

\subsection{Collection of samples:}

A total of 5853 animals slaughtered at ElShohada abattoir, Menofia governorate, Egypt represented by 670 camel, 340 cattle, 366 
buffalo, 3188 young cattle, 502 young buffalo, 544 sheep and 243 goats were examined from 21 Dec., 2017 to 20 Dec., 2018 for detailed postmortem inspection of parasitic infections (Hydatidosis, Fascioliasis, Cysticercosis and Sarcocystosis).

\subsection{Postmortem examination:}

Post mortem examination in slaughtered food animals was carried out through visual inspection, palpation and incision of edible offals for detection of hydatidosis, fascioliasis, cysticercosis and macroscopic sarcocysts according to Gracey (1986).

2.3. Detection of microsarcocysts in examined carcasses by using Polymerase Chain Reaction (PCR):

Application of PCR for identification of D2 region in conserved regions $18 S$ rRNA as species specific gene of Sarcocystis species for buffalo, cow, sheep and goat as well as camel was performed essentially by using primers as shown in the table (A).

\begin{tabular}{|c|c|c|c|c|}
\hline $\begin{array}{l}\text { Target } \\
\text { genes }\end{array}$ & $\begin{array}{l}\text { Primers } \\
\end{array}$ & $\begin{array}{c}\text { Oligonucleotide } \\
\text { sequence }\left(5^{\prime} \rightarrow 3^{\prime}\right)\end{array}$ & $\begin{array}{c}\text { Produc } \\
\text { t size } \\
\text { (bp) }\end{array}$ & Reference \\
\hline $\begin{array}{c}18 S \\
r R N A \\
\text { (Buffal } \\
\text { o, cow, } \\
\text { sheep } \\
\text { \& goat) }\end{array}$ & $\begin{array}{l}\text { SAD } \\
2(F)\end{array}$ & $\begin{array}{c}5^{\prime} \\
\text { GGAAGCGATTGGAAC } \\
\mathrm{C}^{\prime} 3 \\
\\
5^{\prime} \\
\text { A '3 } 3\end{array}$ & 350 & $\begin{array}{l}\text { Latif et } \\
\text { al. } \\
\text { (2015) }\end{array}$ \\
\hline $\begin{array}{c}18 S \\
r R N A\end{array}$ & $\begin{array}{l}\text { A18 } \\
\text { S (F) }\end{array}$ & $\begin{array}{c}5^{\prime} \\
\text { GCACTTGATGAATTCT } \\
\text { GGCA ' } 3^{\prime}\end{array}$ & 539 & $\begin{array}{c}\text { Motam } \\
\text { edi }\end{array}$ \\
\hline (C) & $\begin{array}{c}\text { A18 } \\
\text { S (R) }\end{array}$ & $\begin{array}{c}5^{\prime} \\
\text { CACCACCCATAGAAT } \\
\text { CAAG ' } 3^{\text {CAA }}\end{array}$ & & $\begin{array}{l}\text { et al. } \\
\text { (2011) }\end{array}$ \\
\hline
\end{tabular}

\subsection{DNA extraction (Silva et al., 2009):}

The samples were minced by an electric meat grinder and 25-30 $\mathrm{mg}$ of each minced tissue was used following the manufacturer's instructions of a commercial DNA extraction kit (Qiagen,Valencia, CA, USA). The samples were resuspended in $180 \mu \mathrm{l}$ ATL buffer and $20 \mu 1$ proteinase K (QIAamp DNA Mini Kit), and the protocol recommended for tissue samples was followed. All DNA extracts were stored at $-20{ }^{\circ} \mathrm{C}$ until used. This product was used as a template for PCR. 3.2. DNA amplification:

\subsubsection{Amplification of $18 S$ rRNA gene of} buffalo, cow, sheep and goat Sarcocystis (Latif et al., 2015):

The amplification was performed on a Thermal Cycler (Master cycler, Eppendorf, Hamburg, Germany). Accurately, reaction mixture consisted of $200 \mathrm{pM}$ of each primer, $25 \mu 1$ of $2 X$ PCR Master Mix, $2 \mu 1$ DNA template, and topped with nuclease-free water to a volume of $50 \mu 1$. The thermal profile consisted of initial denaturation at $94^{\circ} \mathrm{C}$ for 2 minutes, followed by 40 cycles of 30 seconds denaturation at $95^{\circ} \mathrm{C}, 30$ seconds annealing at $55^{\circ} \mathrm{C}$, and 1 minute extension at $72^{\circ} \mathrm{C}$, with 10 minutes final extension at $72^{\circ} \mathrm{C}$. The amplified DNA products were elecrophoresed through $1.5 \%$ agarose solution in $1 \mathrm{x}$ TBE electrophoresis buffer at $80 \mathrm{~V}$ for 100 minutes. Finally, the gel was stained with ethidium bromide and captured as well as visualized on UV transilluminator. A $100 \mathrm{bp}$ plus DNA Ladder (Qiagen, Germany, GmbH) was used to determine the fragment sizes. 3.2.2. Amplification of $18 S$ rRNA gene of camel Sarcocystis (Motamedi et al., 2011):

The PCR was performed ( $30 \mu 1$ reactions) using $1 \mu \mathrm{l}(10 \mathrm{pM})$ of each primer, $0.5 \mu \mathrm{l}$ Taq polymerase, $0.5 \mu 1 \mathrm{dNTP}, 2 \mu \mathrm{MgCl} 2,10 \mu \mathrm{l}$ DNA, $3 \mu$ buffer $10 \times$ and $12 \mu$ distilled water. Reactions were carried out on an Eppendorf Master Cycler Gradient thermal cycler. The PCR required a preliminary denaturation at $94^{\circ} \mathrm{C}$ for $5 \mathrm{~min}$. The remaining PCR steps were 35 cycles at $94^{\circ} \mathrm{C}$ $(2 \mathrm{~min}), 57^{\circ} \mathrm{C}(30 \mathrm{sec}), 72^{\circ} \mathrm{C}(2 \mathrm{~min})$, with a single terminal step at $72^{\circ} \mathrm{C}(5 \mathrm{~min})$. The amplified DNA fragments were analyzed by 
$1.5 \%$ of agarose gel electrophoresis in $1 \mathrm{x}$ TBE buffer stained with ethidium bromide.

\section{RESULTS}

The results revealed that the total incidence of hydatidosis during the period of the study was $2.2 \%$. The incidence of hydatidosis is higher in camel $(18 \%)$ than cattle $(0.3 \%)$ and buffalo $(0.5 \%)$, but couldn't be detected in young cattle, young buffalo, sheep and goat (Table, $1)$. The incidence in lungs $(8.7 \%)$ was higher than in livers $(0.4 \%)$ and hydatid cysts couldn't be detected in kidneys (Table 2). According to seasonal variation, the highest incidence in camels was recorded in winter $(21 \%)$, while in cattle was recorded in spring $(1 \%)$, but in buffalo was in summer $(1.8 \%)$ (Table 3). The results revealed that the total incidence of fascioliasis was $0.26 \%$. The incidence of fascioliasis is $0.9 \%$ in camel, $0.8 \%$ in buffalo and the incidence was higher in cattle $(1.2 \%)$ than young one $(0.1 \%)$. Fascioliasis couldn't be detected in young buffalo, sheep and goat (Table 1). Meanwhile, the highest incidence in buffalo, cattle, young cattle and camel was in spring $(1.7 \%)$, winter (4.8\%), spring $(0.2 \%)$ and winter $(1.8 \%)$, respectively (Table 4). Cystecercosis couldn't be detected in edible offals of slaughterd animals during post-mortem inspection (Table 1). The results showed that the total incidence of macroscopic sarcocystosis was $3.9 \%$. The incidence of macroscopic sarcocystosis was higher in buffalo $(62.8 \%)$ than young buffalo $(0.2 \%)$ (Table 1). In buffalo, the incidence was higher in esophagus (54\%) than in tongue (8.7\%), but in young buffalo, the esophagus was only infected $(0.2 \%)$ (Table 5). The autumn is considered the season of the higher incidence $(81 \%)$ and $(1.5 \%)$ of macroscopic sarcocystosis in buffalo and young ones, respectively (Table 6). The results of PCR for detection of microscopic sarcosystosis in 15 esophageal samples in photograph (1) showed that three samples of suspected buffaloes were confirmed positive by PCR, while one sample out of three were confirmed positive for apparently healthy buffaloes. One sample out of three was confirmed positive for cattle. Two samples out of three were confirmed positive for sheep. One sample out of three was confirmed positive for goat. The result of PCR for three samples from camel in photograph (2) showed that all samples were confirmed negative.

Table1: Incidence of parasitic affections (Hydatidosis, Sarcocystois, Fascioliasis and Cysticercosis) of edible offals in food slaughtered animals during detailed post- mortem examination.

\begin{tabular}{|c|c|c|c|c|c|c|c|c|}
\hline \multirow{3}{*}{ Species } & \multirow{3}{*}{$\begin{array}{l}\text { No of } \\
\text { examined } \\
\text { carcasses }\end{array}$} & \multicolumn{6}{|c|}{ Parasite affections } & \\
\hline & & \multicolumn{2}{|c|}{ Hydatid cyst } & \multicolumn{2}{|c|}{ Sarcocyst } & \multicolumn{2}{|l|}{ Fasciola } & Cysticercus \\
\hline & & +ve No. & $(\%)$ & + ve No & $(\%)$ & +ve No. & $(\%)$ & +ve No. $\quad(\%)$ \\
\hline Camel & 670 & 123 & $18 \%$ & \multicolumn{2}{|c|}{ Couldn't be recorded } & 6 & $0.9 \%$ & \\
\hline Cattle & 340 & 1 & $0.3 \%$ & & & 4 & $1.2 \%$ & \\
\hline Buffalo & 366 & 2 & $0.5 \%$ & 230 & $62.8 \%$ & 3 & $0.8 \%$ & \\
\hline Young cattle & 3188 & & & \multicolumn{2}{|c|}{ Couldn't be recorded } & 2 & $0.1 \%$ & Couldn't be recorded \\
\hline Young buffalo & 502 & & & 1 & $0.2 \%$ & & & \\
\hline Sheep & 544 & \multirow{2}{*}{\multicolumn{2}{|c|}{$\begin{array}{l}\text { Couldn't be } \\
\text { recorded }\end{array}$}} & \multirow{2}{*}{\multicolumn{2}{|c|}{ Couldn't be recorded }} & \multirow{2}{*}{\multicolumn{2}{|c|}{$\begin{array}{l}\text { Couldn't be } \\
\text { recorded }\end{array}$}} & \\
\hline Goat & 243 & & & & & & & \\
\hline Total & 5853 & 126 & $2.2 \%$ & 231 & $3.9 \%$ & 15 & $0.26 \%$ & \\
\hline
\end{tabular}


Table 2: Incidence of hydatid cyst in edible offals of slaughtered animals during detailed postmortem examination.

\begin{tabular}{|c|c|c|c|c|c|c|}
\hline \multirow[t]{3}{*}{ Animal spp. } & \multirow[t]{3}{*}{ No. of slaughtered } & \multicolumn{5}{|c|}{ Affected offals } \\
\hline & & \multicolumn{2}{|c|}{ Lung } & \multicolumn{2}{|c|}{ Liver } & Kidney \\
\hline & & Positive NO. & $(\%)$ & Positive NO. & $(\%)$ & Positive NO. \\
\hline Camel & 670 & 117 & $17 \%$ & 6 & $0.9 \%$ & \\
\hline Cattle & 340 & 1 & $0.3 \%$ & \multicolumn{2}{|c|}{ Couldn't be recorded } & Couldn't be recorded \\
\hline Buffalo & 366 & 2 & $0.5 \%$ & & & \\
\hline Total & 1376 & 120 & $8.7 \%$ & 6 & $0.4 \%$ & \\
\hline
\end{tabular}

Table 3: Incidence of hydatid cyst according to seasonal variation from 22 Dec. 2017 to 2018.

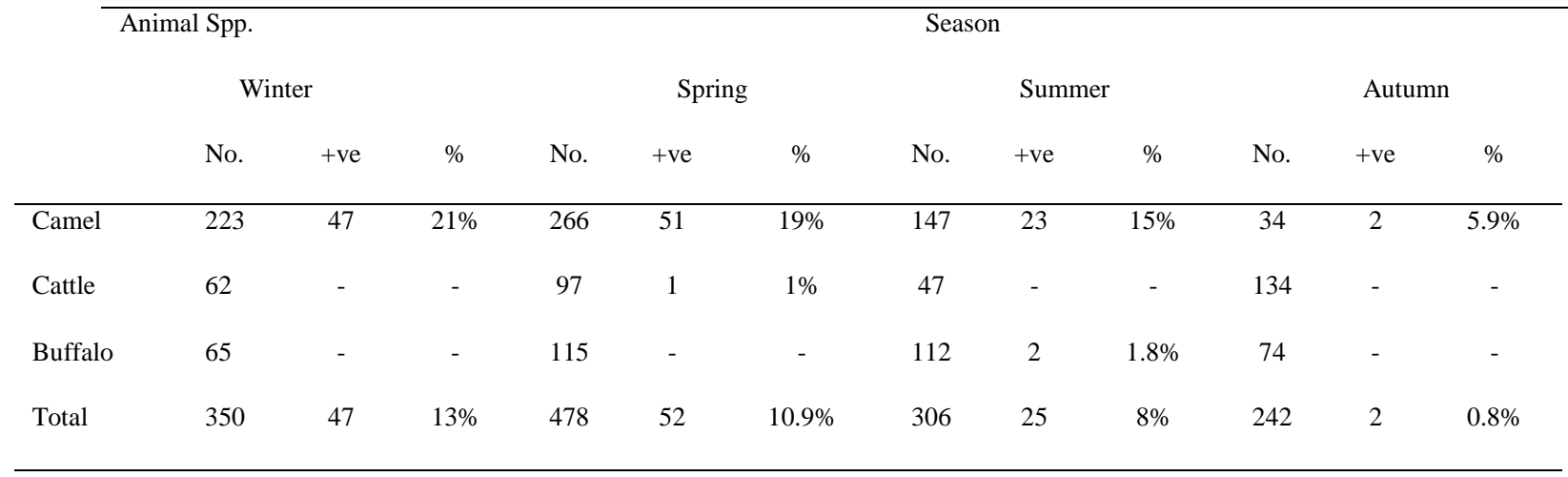

Table 4: incidence $\%$ of Fasciola species in liver of different slaughtered animals according to seasonal variation from 22 Dec., 2017 to 21 Dec., 2018.

\begin{tabular}{ccccccccccccc}
\hline & \multicolumn{3}{c}{ Winter } & \multicolumn{3}{c}{ Spring } & \multicolumn{3}{c}{ Summer } & \multicolumn{3}{c}{ Autumn } \\
& No. & + ve & $\%$ & No. & + ve & $\%$ & No. & + ve & $\%$ & No. & +ve & $\%$ \\
Buffalo & 65 & - & - & 115 & 2 & $1.7 \%$ & 112 & 1 & $0.8 \%$ & 74 & Couldn't be \\
Cattle & 62 & 3 & $4.8 \%$ & 97 & 1 & $1 \%$ & 47 & - & - & 134 & recorded \\
$\begin{array}{c}\text { Young } \\
\text { cattle }\end{array}$ & 762 & - & - & 980 & 2 & $0.2 \%$ & 831 & - & - & 615 & \\
Camel & 223 & 4 & $1.8 \%$ & 266 & 2 & $0.8 \%$ & 147 & - & - & 34 \\
Total & 1112 & 7 & $0.6 \%$ & 1458 & 70 & $0.5 \%$ & 1137 & 1 & $0.1 \%$ & 857 \\
\hline
\end{tabular}

Table 5: Incidence \% of Sarcocyst fusiforms in edible offals of old and young slaughtered buffalo from 22 Dec., 2017 to 21 Dec., 2018.

\begin{tabular}{|c|c|c|c|c|c|c|c|c|}
\hline \multirow[t]{3}{*}{ Animal spp. } & \multirow[t]{3}{*}{ slaughtered No. } & \multicolumn{7}{|c|}{ Affected offals } \\
\hline & & \multicolumn{2}{|c|}{ Esophagus } & \multicolumn{2}{|c|}{ Tongue } & \multicolumn{3}{|c|}{ Total } \\
\hline & & Positive NO. & $(\%)$ & Positive NO. & $(\%)$ & Posit & NO. & $(\%)$ \\
\hline Old buffalo & 366 & 198 & $54 \%$ & 32 & $8.7 \%$ & 230 & 62.8 & \\
\hline Young buffalo & 502 & 1 & $0.2 \%$ & Couldn't be & corded & 1 & 0.29 & \\
\hline Total & 868 & 199 & $22.9 \%$ & 32 & $3.7 \%$ & 231 & 26.6 & \\
\hline
\end{tabular}


Table 6: Incidence \% of Sarcocyst fusiforms on Tounge and oesophagus of old and young buffalo carcasses during detailed post- mortem examination from 22 Dec., 2017 to 21 Dec., 2018.

\begin{tabular}{|c|c|c|c|c|c|c|c|c|c|c|c|c|}
\hline & \multicolumn{3}{|c|}{ Winter } & \multicolumn{3}{|c|}{ Spring } & \multicolumn{3}{|c|}{ Summer } & \multicolumn{3}{|c|}{ Autumn } \\
\hline & No. & $+\mathrm{ve}$ & $\%$ & No. & $+\mathrm{ve}$ & $\%$ & No. & $+\mathrm{ve}$ & $\%$ & No. & $+\mathrm{ve}$ & $\%$ \\
\hline Old Buffalo & 65 & 33 & $50 \%$ & 115 & 77 & $66 \%$ & 112 & 60 & $53 \%$ & 74 & 60 & $81 \%$ \\
\hline $\begin{array}{l}\text { Young } \\
\text { Buffalo }\end{array}$ & 122 & - & - & 188 & - & - & 124 & - & - & 68 & 1 & $1.5 \%$ \\
\hline Total & 187 & 33 & $17 \%$ & 303 & 77 & $25 \%$ & 236 & 60 & $25 \%$ & 142 & 61 & $42 \%$ \\
\hline
\end{tabular}

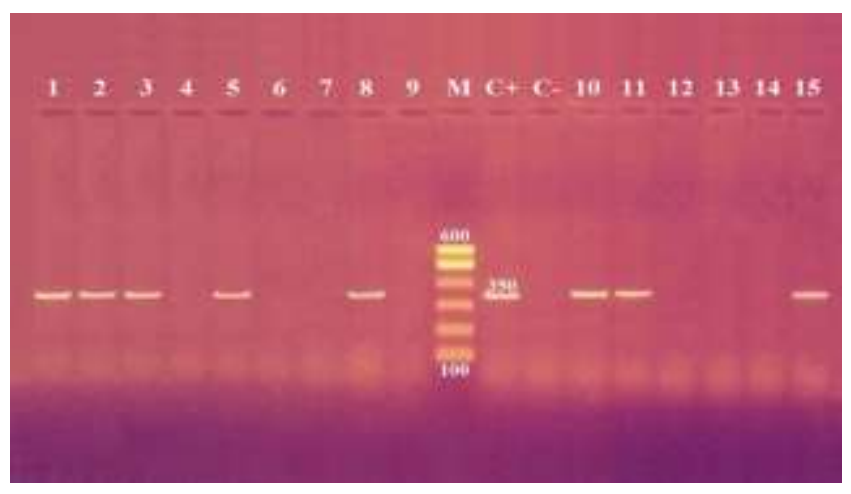

Fig.1. Agarose gel electrophoresis of PCR of $18 \mathrm{~S}$ rRNA gene (350 bp) for identification of Sarcocystis species in buffalo, cow, sheep and goat tissues.

Lane M: 100 bp ladder as molecular size DNA marker.

Lane C+: Control positive Sarcocystis species for 18S rRNA., Lane C-: Control negative.

Lanes 1, 2 \& 3 (suspected buffalo), 5 (apparently healthy buffalo), 8 (cow), 10, 11 (sheep) \& 15 (goat): Positive bands for Sarcocystis species. Lanes 2, 6 (apparently healthy buffalo), 7, 9 (cow), 12 (sheep), $13 \& 14$ (goat): Negative bands for Sarcocystis species.

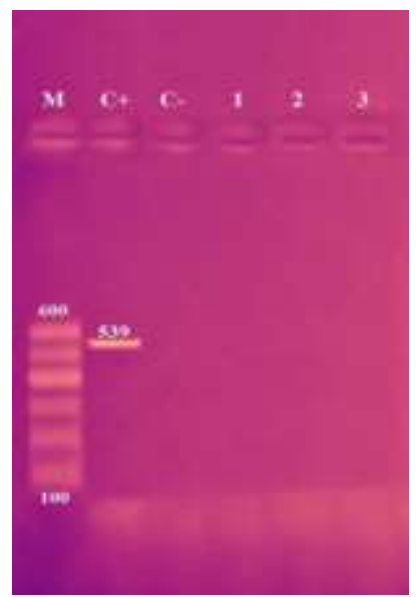

Fig.2. Agarose gel electrophoresis of PCR of 18S rRNA gene (539 bp) for identification of Sarcocystis species in camel tissues.

Lane M: 100 bp ladder as molecular size DNA marker.

Lane C+: Control positive Sarcocystis species for 18S rRNA, Lane C-: Control negative.

Lanes 1, 2 \& 3: Negative bands for Sarcocystis species. 


\section{DISCUSSION}

The regular re-evaluation of the current status of zoonotic parasitic diseases is needed to obtain enough information that will provide inputs in the design and implementation of control strategies (Komba, 2017). The results revealed that the total incidence of hydatidosis was disagreed with high incidence $(4.23 \%)$ recorded in Tibet Autonomous Region (TAR) and lower incidence $(0.24 \%)$ recorded in China by $\mathrm{Li}$ et al. (2019). The highest incidence of hydatid cyst recorded in camel was nearly similar to the incidence (16\%) that was recorded in Mekka-AlMukarama by Haroun et al. (2010). This result disagreed with low incidence $(2.53 \%)$ recorded by Haridy et al. (2006) in Egypt and high incidence (40\%) recorded by Khan et al. (2001) in Libya. In addition, the incidence in offals of slaughtered camels agree with Shahat, (2000) and Dyab et al. (2005) in Egypt who mentioned that the lung was the predominant predilection site for Echinococcus granulosus larvae. In addition, the highest incidence in camels disagrees with Dyab et al. (2005) who mentioned that the highest incidence in Egypt was recorded in summer. The results revealed that the incidence of hydatid cyst in cattle was nearly similar to the incidence $(0.4 \%)$ that was recorded in Nigeria by Tijjani et al. (2010). This result disagrees with Dyab et al. (2005) in Egypt who couldn't record any hydatid cyst and Beyene and Hiko (2019) who recorded that the incidence was $33.3 \%$ in Ethiopia. Higher result was recorded by Chihai et al. (2016) who recorded that the incidence was $59.3 \%$ in the Republic of Moldova. In addition, the incidence of hydatid cysts in offals of slaughtered cattle disagree with Salem et al. (2011) who reported that the most predilection site was the liver and Mitrea et al. (2012) who recorded three cattle had cysts in kidney. In addition, the incidence in slaughtered cattle according to seasonal variation disagrees with Berhe (2009) who reported that the prevalence of hydatidosis was the highest in July and the lowest in April (25.11\%). Concerning buffalo, the results revealed that the incidence of hydatid cyst disagree with Dyab et al. (2005) who couldn't record any hydatid cyst in Egypt and Samavation et al. (2009) who recorded that the incidence was $(31.87 \%)$ in buffalo. In addition, the incidence according to seasonal variation in buffalo disagree with Beyhan and Umur (2010) who could detect hydatid cysts in the liver of slaughtered buffalo. The results revealed the incidence in sheep disagree with very high result (61.9\%) recorded by Chihai et al. (2016) in the Republic of Moldova. Low incidence $(0.3 \%)$ and $(1.06 \%)$ were recorded by Haridy et al. (2006) in Egypt and Esam Almalki et al. (2017) in Saudi Arabia, respectively. Regarding goats, the results disagree with very high incidence (40\%) recorded by Khan et al. (2001) in Libya and low incidence $(0.68 \%)$ recorded by Haridy et al. (2006) in Egypt. The variation in hydatidosis incidence rate may be due to changes in the environmental condition in different countries, the applied hygienic measures, the methods of control inside abattoirs, the contamination rate in the intermediate hosts, the number of dogs in each area, the slaughtering manner and the feeding status of slaughtered animals. The results showed that the total incidence of fascioliasis disagree with Kouam et al. (2019) who mentioned that the incidence of fascioliasis was $22.62 \%$ in Cameroon. The results of the incidence of fascioliasis in slaughtered animals disagree with Abraham and Jude (2014) who found that $36 \%$ (126/350) of goat had fascioliasis at Calabar abattoirs in Nigeria, Vreni et al. (2014) who recorded that the prevalence of fascioliasis was $23 \%$ in sheep in south-eastern Lake Chad area and Elshraway et al. (2017) who mentioned that the incidence of fascioliasis 
was $30.88 \%(695 / 2251)$ in cattle and bovine carcasses in Egypt. In addition, the incidence in cattle, buffalo and camel according to seasonal variation disagree with Kasim et al. (2018) who mentioned that high incidence was in March and April in slaughtered cattle, sheep and goats. The transmission of fascioliasis is depending on the presence of intermediate "lymnaea snail" host and final host. This snail host commonly presents in high density during rainfall period annually and/or in highly moist pastures soil (Abraham and Jude 2014). The results showed that the incidence of cysticercosis was nearly similar to the results recorded by Oryan et al. (2012) who mentioned that only one $C$. ovis cyst was detected in sheep and three $C$. bovis cysts in cattle. These results agreed with Kouam et al. (2019) who mentioned that cysticerci was absent in Cameroon. These results disagree with Beyene and Hiko (2019) who recoded that the incidence of $C$. bovis in 384 randomly selected cattle was $8.6 \%$ in Ethiopia. Also, these results disagree with Abebe et al. (2015) who recorded that $8.43 \%$ of 510 randomly selected slaughtered sheep and $8.5 \%$ of 420 randomly selected slaughtered goats were infected with $C$. ovis. The results of the current work revealed that the incidence of macroscopic Sarcocyst agree with Saeid et al. (2015) who couldn't detect any macroscopic cysts in cattle and disagree with Mounika et al. (2018) who observed macroscopic sarcocysts in nine cattle mainly in esophagus. The incidence in sheep disagrees with Aysen et al. (2007) who found macrocysts of Sarcocyst ovifelis in $(24.5 \%)$ of sheep mainly in esophagus. In addition, the incidence in camel agrees with Hamidinejat et al. (2013) in Iran who mentioned that no macroscopic cyst was observed in the animals at naked eye inspection. Regarding buffalo, the results were nearly similar to the incidence $(66.42 \%)$ obtained by Jyothisree et al. (2016). Polymerase Chain Reaction (PCR) is an effective method used worldwide for confirmation of sarcocysts (Daptardar et al. 2016). DNA extraction and PCR amplification of 18S rRNA gene region was conducted to identify sarcocysts in positive samples in different hosts by using special primers. Other authors detected Sarcocyst species by using PCR as Hornok et al. (2015) in cattle and buffalo in Hungary, Kutty et al. (2015) in goat in Selangor, Malaysia and Safa et al. (2016) in Tunisian cattle in North-West Tunisia.

\section{Conclusion}

The abattoir survey reports still provide good overview of the trend and status of the parasitic zoonoses and can therefore guide in planning future coordinated researches and control programs. The problems of parasitic infestation usually lead to direct or indirect losses in all species of food animals. The direct losses include growth retardation and increased susceptibility to disease, which increase the mortality rate leading to high economic losses. The indirect losses include partial or total condemnation of carcasses after slaughtering inside abattoirs. The incidence of fascioliasis and cysticercosis through the current study gives good impression about their control programs. Hydatidosis stills of high incidence in camel especially in winter and sarcocystosis stills of high incidence in buffalo especially in autumn. Therefore, it is strongly recommended to avoid slaughtering of animals outside abattoirs to prevent zoonosis to human, accurate P.M examination of carcasses in abattoir, sanitary elimination of condemned offals or carcasses of positive parasitic affections with hygienic measures, precautions should be taken in abattoirs to prevent entrance of dogs and cats, avoid eating under-cooked offals, thourlly heat treatment of offals involved in dog and cat diets, finally, using diagnostic methods as PCR for confirmation of microscopic 
sarcocystosis and thoughrly cooking of offals " predilection for microsarcocyst" to prevent zoonotic sarcocystosis.

\section{REFERENCES}

Abebe Tesfaye Gessese, Belay Mulate, Shahid $\mathrm{Na}$ zir And Assefa Asmare (2015): Major metacestodes in small ruminants slaughtered at Cessie municipal abattoir, cyst viability, organ distribution and economic implications. Comparative Clinical Pathology, 24(3): 659-668.

Abraham, J.T. and Jude, I.B., (2014): Fascioliasis in cattle and goat slaughtered at calabar Abattoirs. J. Biol. Agric. Healthc., 4(18):34-41.

Ahmed Youssef (2014): Review of Parasitic Zoonoses in Egypt. Tropical Medicine and Health, 42(1):3-14.

Ahmed Youssef, (2014): Review of Parasitic Zoonoses in Egypt. Tropical Medicine and Health, 42(1):3-14. https://www.researchgate.net/publicatio n/262149397_Review_of_Parasitic_Zo onoses_in_Egypt

Alemneh, T.; Adem, T. and Akeberegn, D. (2017): Mini-Review on Bovine Cysticercosis. Journal of Healthcare Communications, 2: 2.

Ashrafi K, Bargues MD, O'Neill S, MasComa S (2014): Fascioliasis: a worldwide parasitic disease of importance in travel medicine. Travel Med. Infect. Dis., 12(6 Pt A): 636-49.

Aysen BEYAZIT, Oznur YAZICIOGL and Zafer KARAER (2007): The prevalence of ovine Sarcocystis species in Izmir province. Ankara Univ. Vet. Fak. Derg., 54: 111-116.
Berhe, G. (2009): Abattoir survey on cattle hydatidosis in Tigary region of Ethiopia. Trop. Animal Health Prod., $51(1): 33-40$.

Beyene, T. and Hiko, A. (2019): Zoonotic metacestodes and associated financial loss from cattle slaughtered at Yabello municipal abattoir, Borana-Oromia, Ethiopia. Parasite Epidemiol. Control, 5:e00096.

Beyhan, Y.E. and Umur, S. (2010): Molecular charachterization and prevalence of Cystic Echinococcosis in slaughtered Water Buffaloes in Turkey, Vet. Parasitol., 10: 1016 -1021.

Bouree, P. (2001): Hydatidosis: dynamics of transmission. World J. Surg., 25(1): 49.

Chihai, O.; Umhang, G.; Erhan, D.; and Boue, F. (2016): Slaughter house survey of cystic echinococcosis in cattle and sheep from the Republic of Moldova. J. of Helminthology, 90(3):279-283.

Daptardar.Mi; Singh,B.B.; Aulakh,R.S. and Gill,J. P. S. (2016): Prevalence and first molecular identification of Sarcocvstis species in cattle and water buffaloes in lndia.W. Stefanski Institute of ParasitoL, 61 (3):523-528.

Dyab, K. A.; Hassanein, R.; Hussein, A. A.; Metwally, S.E. and Gaad, H. M. (2005): Hydatidosis among man and animals in Assiut and Aswan governorates. Journal of the Egyptian Society of parasitology, 35(1): 157166.

Elshraway, N.T. and Mahmoud, W.G. (2017): Prevalence of fascioliasis (liver flukes) infection in cattle and buffaloes slaughtered at the municipal abattoir of 
El- Kharga, Egypt. Vet World, 10(8): 914-917.

Erick VG Komba (2017): Aliterature survey of common parasitic zoonoses encountered at post-mortem examination in slaughtered stocks in Tanzania, Economic and puplic health implications. Biomedical Journal of Scintific and Technological Research.

Esam Almalki, Saleh Al-Quarishy and AbdelAzeem S. Abdel-Baki (2017): Assessment of prevalence of hydatidosis in slaughtered Sawakny sheep in Riyadh city, Saudi Arabia.

Gracey, J.F. (1986): Thronton's Meat Hygiene. $8^{\text {th }}$ Ed. English Language Book Society. Baillier Tindall, London.

Hajimohammadi, B.; Eslami, G.; Oryan, A.; Zohourtabar, A.; Pourmirzaei Tafti, H. and Moghaddam Ahmadi, M. (2014): Molecular identification of Sarcocystis hominis in native cattle of central Iran: a case report. Trop. Biomed., 31(1): 183-6.

Hamidinejat, H.; Razi Jalali, M.H.; Gharibi, D. and Molayan, P.H. (2015): Detection of Sarcocystis spp. in cattle (Bos taurus) and water buffaloes (Bubalus bubalis) in Iran by PCR-RFLP. J. Parasit. Dis., 39(4): 658-62.

Haridy, F. M.; Ibrahim, B. B.; El- Shazly, A. M.; Awad, S. E.; Sultan, D. M.; ElSherbini, G. T. and Morsy, T. A. (2006): Hydatidosis in Egyptian slaughtered animals in the years 2000 2005. Journal of the Egyptian Society of parasitology, 36 (3): 1087 -1100.

Haroun, EM; Omer, O.H.; Mahmoud, O.M. and Draz, A. (2010): Serological studies on hydatidosis in camels in
Saudi Arabia. Res. J. Vet. Sci., 3(1):8385.

Hornok, S.; Mester, A.; Takács, N.; Baska, F.; Majoros, G.; Fok, É.; Biksi, I.; Német, Z.; Hornyák, Á.; Jánosi, S. and Farkas, R. (2015): Sarcocystisinfection of cattle in Hungary. Parasit. Vectors, 8:69.

Hamidinejat, $\quad$ H.; $\quad$ Seyed hossein Hekmatimoghaddam, Hedieh Ja fari, Alireza Sazmand, Pedram Haddad Molayan, Leila Derakhshan and Seyedmehdi Mirabdollahi (2013): Prevalence and distribution patterns of Sarcocystis in camels (Camelus dromedarius) in Yazd province, Iran. Journal of Parasitic Diseases, 37(2): 163-165.

Ifeoma Nancy Obijiaku, Ikwe Ajog, Jarlath Udoudo Umoh, Idris Alao Lawal and Bernard Ortwer Atu. (2013): Sarcocystis infection in slaughtered cattle in Zango abattoir, Zaria, Nigeria.Vet. World., 6(6): 346-349.

JyothiSree, Ch.; Venu, R.; Samatha, V.; Malakondaiah, P. and Rayulu, V. C. (2017): Prevalence and microscopic studies of Sarcocystis infection in naturally infected water buffaloes (Bubalus bubalis) of Andhra Pradesh. Journal of Parasitic Diseases, 41(2): 476-482.

Kasim Sakran Abass, Esraa Khalil Ibrahim, Rana Noori Khalaf and Rasha Hisham Esmail (2018): Prevalence of liver Fluke infections in slaughtered animals in Kirkuk province, Iraq. IMedPup Journals, 2(2): 05.

Khan, A.H.; El-Buni, A.A. and Ali, M.Y. (2001): Fertility of the cysts of Echinococcus granulosus in domestic 
herbivores from Benghazi, Libya and the reactivity of antigens produced from them. Ann. Trop. Med. Parasitol., 95(4): 337-342.

Kouam, M.K.; Meningue, R. and Fon, D.E. (2019): Parasitic causes of organ condemnation in cattle slaughtered in Fako abattoirs, South-West region of Cameroon, and estimate of financial losses. J.Helminthol., 93(3): 367-371.

Latif, B.; Kannan Kutty, M.; Muslim, A.; Hussaini, J.; Omer, E.; Heo, C.; Rossle, N.; Abdullah, S.; Kamarudin, M. and Zulkarnain, M. (2015): Light microscopy and molecular identification of Sarcocystis spp. in meat producing animals in Selangor, Malaysia. Tropical Biomedicine, 32 (3): 1-9.

Li, B.; Quzhen, G.; Xue, C.Z.; Han, S.; Chen, W.Q.; Yan, XL.; Li, Z.J.; Quick, M.L.; Huang, Y.; Xiao, N.; Wang, Y.; Wang, L.Y.; Zuoga, G.; Bianba; Gangzhu; Ma,

B.C.; Gasong; Wei, X.G.; Niji; Zheng, C.J.; Wu, W.P and Zhou, X.N. (2019): Epidemiological survey of echinococcosis in Tibet Autonomous Region of China. Infect. Dis. Poverty, 8(1): 29.

Mason, C. (2004): Fasciolosis associated with metabolic disease in a dairy herd, and its effects on health and productivity. Cattle Pract., 12: 7-13.

Mitrea, I.L.; Ionita, M.; Wassermann, M.; Solcan, G. and Romig, T (2012): Cystic ecinococcosis in Romania: an epidemiological survey of livestock demonstrates the persistence of hyperendemicity. Foodborne Pathog Dis., 9(11): 980-5.
Motamedi, G.; Dalimi, A.; Nouri, A. and Aghaeipou, K. (2011): Ultrastructural and molecular characterization of Sarcocystis isolated from camel (Camelus dromedarius) in Iran. Parasitol. Res. 108: 949-954.

Mounika, K.; Chennuru, S.; Ravipati, V.; Tumati, S.R. and Krovvidi, S. (2018): Studies on prevalence and histomorphology of Sarcocystis species infecting cattle in Andhra Pradesh, India. J. Parasit. Dis., 42(1): 77-80.

Oryan, A.; Goorgipour, S.; Moazeni, M. and Shirian, S. (2012): Abattoir prevalence, organ distribution, puplic health and economic importance of major metacestodes in sheep, poats and cattle in Fars, southern Iran. Tropical Biomedicine, 29(3): 349-359.

Saeid R. Nourollahi-Fard, Reza Kheirandish and Saeid Sattari (2015): Prevalence and histopathological finding of thinwalled and thick-walled Sarcocysts in slaughtered cattle of Karaj abattoir, Iran. Journal of Parasitic Diseases, 39(2): 272-275.

Safa Amairia, Yosra Amdounia, Mohamed Ridha Rjeibi, Mariem Rouatbi and Sofia Awadib Mohamed Gharbia (2016): First molecular detection and characterization of Sarcocystis species in slaughtered cattle in North-West Tunisia. Meat Science, 122: 55-59.

Salem, C.B.O.A.; Schneegans, F.; Chollet, J.Y. and Jemli, M.H. (2011): Epidemiological studies on Echinococcosis and characterization of Humans and livestock hydatid cysts in Mauritania. Iranian J. Parasitol., 6 (1): 49-57. 
Samavatian, A.; Valilou, M.R.; Lotfi, A.R.; Khani, M.Y. and Mirzaei, H. (2009): Study of the incidence rate of liver and lung hydatidosis in slaughtered cattle and buffalo, at Ahar abattoir during 2007-2008. Buffalo Bulletin, 28(4): 218-222.

Scott Smith (2004): Sarcocystis. http:// web.stanford.edu.

Shahat, A.A. (2000): Prevalence of hydatidosis in slaughtered food animals. J. Egypt. Vet. Med. Ass., 60 (4):147-150.

Silva, R.; Chunlei, S. and Langoni, H. (2009): First identification of Sarcocystis tenella by PCR in naturally infected sheep from Brazil. Vet Parasitol. 165: 332-336.
Tijjani, A.O.; Musa, H.I. and Atsanda, N.N. (2010): Prevalence of hydatid disease in cattle and camel slaughtered at Damaturu Abattoir, Nigeria. Sahel J. of Vet. Sciences, 9(1): 195-198.

Vreni Jean-Richard,Lisa Crump, Abbani Alhadi Abicho, Ngandolo Bongo Nare, Helena Greter, Jan Hattendorf, Esther Scheling andJakob Zinsstag (2014): Prevalence of Fasciola gigantica infection in slaughtered animals in southeastern Lake Chad area in relation to Husbandry practices and seasonal water levels. BMC Vet. Res., 10: 81. 